\title{
Condition and Dynamics of the Russian Far East Forests in 1966-1993
}

\author{
Valentine Chelyshev*1 and Nobuyuki Abe*2
}

\begin{abstract}
The Russian Far East Forests are a great ecological and natural resource of significance to the for Asia - Pacific region. Evaluation of the condition and dynamics of these forests helps in the evaluation of sustainable forest use trends in nature protection activities and the identification of research needs. In this paper, the condition of the Forest Service land as at January 1993 is described and the forest dynamics between 1966 and 1993 is analyzed. On the basis of the analysis of the forests' condition and dynamics, the ecological and timber potential of the Far East forests is evaluated.
\end{abstract}

Keyword: Russian forestry, Russian Far East forest, Forest resources

\section{INTRODUCTION}

This article is the result of scientific collaboration between Niigata University and the Far East Forestry Research Institute (Khabarovsk city). The Japan - Russia International forum "Current condition of Siberia forests" which took place in Niigata (August 1994) emphasized the importance of studying Siberian and Far Eastern forests by joint Russian-Japanese efforts. Siberian and the Far Eastern forests are of great interest to Japan, firstly because of their ecological significance in the Asia - Pacific Region, and secondly because these forests represent a vast timber resource.

The Russian Far East forests have been described in many scientific publications, including detailed descriptions of their condition and dynamics (KzECHETOV et al. 1975, The Far East forests 1969, Krechetov et al. 1975, Sheingauz and Chyolyshev 1984, Sheingauz 1989, etc.) . However, most of these publications are in Russian and are mostly inaccessible to readers in other countries.

The Russian Far East is defined here as including the limits of Primorski and Khabarovski krais; The Amurs- kaya, Kamchatskaya, Magadanskaya and Sakhalinskaya oblasts; the SAKhA Republic (Yakutia); the Jewish autonomous oblast and the Koryaksky autonomous district (Fig. 1). This territory covers 506.9 m.ha of mainly of undeveloped and almost unexplored forests (Table 1). Most of the forests were surveyed remotely using space and air photo interpretation. Inventory data are between 1 and 30 years old. A small part of the forests was surveyed by ground inventory. These inventory data are between 1 and 20 years old. On the basis of existing data collected at different time periods, once every five years inventory accounts are compiled for the whole of Russia. Comparison of inventory data collected at different times, was done by extrapolation, after taking into account fires, logging, diseases, pests, natural ageing and other factors which influences the dynamics of forests of the Forest Service land. Since the effects of these factors on the Forest Service land was hard to predict precisely, the precision of extrapolated inventory data was low.

Therefore, the peculiarities of forest inventory in the Russian Far East should be remembered and analysis lim. ited to evaluating proportions and trends as indices of structural qualitative changes.

*1 Far East Forestry Research Institute, Volochaevskaya, 71, 680020 Khabarovsk, Russia

*2 Faculty of Agriculture, Niigata University, 8050 Ikarashininocho, Niigata, 950-21, Japan 


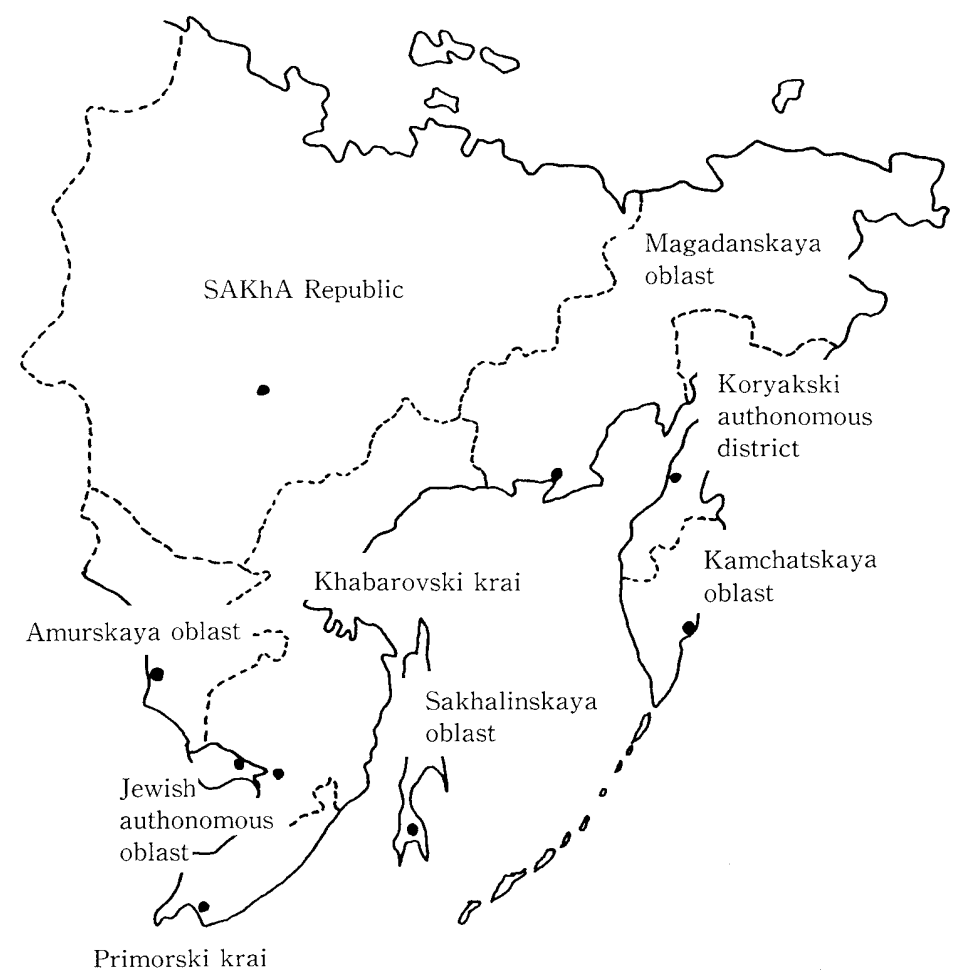

Fig. 1 Sketch map of Russian Far East territorial unit

\section{RESULTS AND DISCUSSION}

\section{Forest Condition}

The forest condition described here is for 1 January 1993, the date of the compilation of the last forest resources inventory.

Forest Service land makes up most of the land area in the Far East. The smallest proportion of land that is in Forest Service control is in the Magadanskaya oblast $(61 \%)$ and in the Jewish autonomous oblast $(64 \%$, Table 1). In the Khabarovski krai and the Koryakski autonomous district, $96 \%$ of the land is in Forest Service contrail. In the Far East as a whole, $82 \%$ of the area is managed by the Forest Service.

The Far Eastern Forest Service land is under the jurisdiction of several land holders. Its main portion $(498.2$ m.ha or $98 \%$ ) belongs to the Russian Federal Forest Service and its subdivisions in the Russian Federation (krai, oblast, republic, etc.). Although the area under the jurisdiction of other land holders is vast $(8.7 \mathrm{~m} . \mathrm{ha})$, it makes up only $1.7 \%$ of the total Far Eastern forests. Such management centralization allows a common forestry policy. Only the condition and dynamics of the forests of the Russian Federal Forest Service are analyzed in this paper.

Forest Service land consists of forest and nonforest lands. Nonforest lands include swamps, waters, stony outcroppings on steep slopes, sands, grazing grounds, agricultural fields, roads, cleared strips and other lands not intended for growing tree shrub species. Some districts have a high proportion of nonforest land, the Koryaksky autonomous district (61\%), and the Magadanskaya (48\%) and Kamchatskaya (37\%) oblasts (Table 2). Overall, nonforest land covers $30 \%$ of Forest Service land in the Far East (147.3 m.ha).

Forest land consists of closed stands, brush thickets, unclosed stands, dead stands and open woodlands. Unclosed and dead stands include open woodlands with densities less than 0.3 and land not covered by forest because of natural or anthropogenic destruction (fires, windthrow, loggings etc.). Unclosed and dead stands are very common in Khabarovski krai (14\%), Magadanskaya oblast (14\%), Amurskaya oblast (12\%), SAKhA Republic (Yakutia) $(12 \%)$ and Sakhalinskaya oblast (11\%). Overall, $40.2 \mathrm{~m}$. ha $(11 \%)$ of closed stands in the Far East are thinned or damaged. These areas slowly convert back to closed stands, resulting in the area of close stands enlarging.

Open woodlands are stands with a density less than 0.3 which have formed naturally because of severe conditions (high in the mountains, on stony outcroppings, in forest tundra, on overmoist soils et.). Open woodlands of the Far East make up about 36.6 m.ha (Table 2). Precise inventory of these lands was not done. In the Forest Service 
Table 1 Distribution of land between management agencies in the Russian Far East

\begin{tabular}{|c|c|c|c|c|c|}
\hline \multirow{3}{*}{ Territorial units } & \multicolumn{5}{|c|}{ Territory } \\
\hline & \multirow[b]{2}{*}{$\begin{array}{l}\text { Total } \\
\text { area }\end{array}$} & \multirow[b]{2}{*}{$\begin{array}{l}\text { Nonforest } \\
\text { Service } \\
\text { land area }\end{array}$} & \multicolumn{3}{|c|}{ Forest Service land base } \\
\hline & & & Total & $\begin{array}{l}\text { The Russia } \\
\text { Federal Forest } \\
\text { Service }\end{array}$ & $\begin{array}{l}\text { Other } \\
\text { ministries and } \\
\text { agencies }\end{array}$ \\
\hline 1 & 2 & 3 & 4 & 5 & 6 \\
\hline $\begin{array}{c}\text { Primorski krai, m.ha } \\
\%\end{array}$ & $\begin{array}{l}16.5 \\
100\end{array}$ & $\begin{array}{l}3.3 \\
20\end{array}$ & $\begin{array}{l}13.2 \\
80\end{array}$ & $\begin{array}{l}11.9 \\
72\end{array}$ & $\begin{array}{l}1.3 \\
8\end{array}$ \\
\hline $\begin{array}{c}\text { Khabarovski krai, m.ha } \\
\%\end{array}$ & $\begin{array}{l}78.8 \\
100\end{array}$ & $\begin{array}{l}3.3 \\
4\end{array}$ & $\begin{array}{l}75.5 \\
96\end{array}$ & $\begin{array}{l}73.9 \\
94\end{array}$ & $\begin{array}{l}1.6 \\
2\end{array}$ \\
\hline $\begin{array}{c}\text { Amurskaya oblast, m.ha } \\
\%\end{array}$ & $\begin{array}{l}36.2 \\
100\end{array}$ & $\begin{array}{c}4.5 \\
12\end{array}$ & $\begin{array}{l}31.7 \\
88\end{array}$ & $\begin{array}{l}30.7 \\
85\end{array}$ & $\begin{array}{l}1.0 \\
3\end{array}$ \\
\hline $\begin{array}{c}\text { Kamchatskaya oblast, m.ha } \\
\%\end{array}$ & $\begin{array}{l}17.1 \\
100\end{array}$ & $\begin{array}{l}0.8 \\
5\end{array}$ & $\begin{array}{l}16.3 \\
95\end{array}$ & $\begin{array}{l}15.0 \\
88\end{array}$ & $\begin{array}{l}1.3 \\
7\end{array}$ \\
\hline $\begin{array}{c}\text { Magadanskaya oblast, m.ha } \\
\%\end{array}$ & $\begin{array}{l}119.9 \\
100\end{array}$ & $\begin{array}{l}46.2 \\
39\end{array}$ & $\begin{array}{l}73.7 \\
61\end{array}$ & $\begin{array}{l}71.7 \\
59\end{array}$ & $\begin{array}{l}2 \\
2\end{array}$ \\
\hline $\begin{array}{c}\text { Sakhalinskaya oblast, m.ha } \\
\%\end{array}$ & $\begin{array}{l}8.7 \\
100\end{array}$ & $\begin{array}{l}1.3 \\
15\end{array}$ & $\begin{array}{l}7.4 \\
85\end{array}$ & $\begin{array}{l}6.9 \\
79\end{array}$ & $\begin{array}{l}0.5 \\
6\end{array}$ \\
\hline $\begin{array}{c}\text { SAKhA Republic (Yakutia), } \\
\text { m.ha }\end{array}$ & 310.3 & 52.4 & 257.9 & 257.0 & $\underset{2)}{0.9}$ \\
\hline $\begin{array}{c}\text { Jewish authonomous oblast, } \\
\text { m.ha } \\
\%\end{array}$ & 100 & $\begin{array}{l}1.3 \\
36\end{array}$ & $\begin{array}{l}2.3 \\
64\end{array}$ & $\begin{array}{l}2.2 \\
61\end{array}$ & $\begin{array}{l}0.1 \\
3\end{array}$ \\
\hline $\begin{array}{c}\text { Koryakski authonomous } \\
\text { district, m.ha } \\
\%\end{array}$ & $\begin{array}{l}30.1 \\
100\end{array}$ & $\begin{array}{l}1.2 \\
4\end{array}$ & $\begin{array}{l}28.9 \\
96\end{array}$ & $\begin{array}{l}28.9 \\
96\end{array}$ & $\begin{array}{l}\text { 1) } \\
\text { 2) }\end{array}$ \\
\hline $\begin{array}{c}\text { Far East, m.ha } \\
\%\end{array}$ & $\begin{array}{l}621.2 \\
100\end{array}$ & $\begin{array}{c}114.3 \\
18\end{array}$ & $\begin{array}{c}506.9 \\
82\end{array}$ & $\begin{array}{c}498.2 \\
80\end{array}$ & $\begin{array}{l}8.7 \\
2\end{array}$ \\
\hline
\end{tabular}

1) less than 0.05 m.ha

2) less than $0.5 \%$

Source: Data base of the Far East Forestry Research Institute, 1995

land base inventory of 01.01.1993 they were included as open land (forest land not covered by forest vegetation). They are common in Magadanskaya oblast (26\%) and in SAKhA Republic (Yakutia, 12\%).

The area of plantations in the Far East Forest Service land base is insignificant $(0.19 \%$ of forest lands). Almost two thirds of the plantations are included as closed forest stands, but the rest have not yet closed their canopy and are 5-7 years old. Only in Sakhalinskaya oblast and in Jewish autonomous oblast is the share of plantations is relatively high ( 2 and $1 \%$ of forest lands accordingly, Table 2 ). However, even there the plantations do not influence forest use as they are too young for exploitation.

The most valuable resource of the Far East Forest Service land base are account for between the closed stands of natural origin. The forests 59\% (Magadanskaya oblast) and $97 \%$ (Primorski krai) of the forest area. The average for the Far East is 78\% (Table 2).

Coniferous stands are the most common type of closed stands in the Far East $(72 \%$,Table 3$)$. However, in
Koryakski autonomous district, the coniferous stands are only $4 \%$ of the forest area. In this area, brush thickets of Pinus pumila (73\%) and stands of broadleaf species (mostly birch,23\%), prevail. In Kamchatskaya oblast the share of coniferous species is also small (8\%) and stone birch (Betula ermanii) (51\%) and brush thickets (28\%) dominate. Relatively few coniferous stands occur in Jewish autonomous oblast (37\%), in Magadanskaya oblast (43\%) or in Primorski krai (58\%). In Jewish autonomous oblast stands of dwarf oak of coppice origin (Quercus mongolica) and various birches and other broadleaved species are common; in Magadanskaya oblast, shrubs thickets of Pinus pumila are common. The area of broadleaf stands in Primorski krai is high. Most coniferous stands (64\% of all Far East conifer stands) are located in SAKhA Republic (Yakutia) where coniferous species make up $87 \%$ of the closed forest area.

Larch stands (Larix) dominate the coniferous stands of the Far East, accounting for $85 \%$ of the area of coniferous species. However, in Sakhalinskaya oblast and in 
Table 2 Area of Forest Service Land in each vegetation class in each district of the Russian Far East

\begin{tabular}{|c|c|c|c|c|c|c|c|c|c|}
\hline \multirow{3}{*}{ Territorial units } & \multicolumn{9}{|c|}{ Land base of the Russian Federal Forest Service } \\
\hline & \multirow{2}{*}{$\begin{array}{c}\text { Total } \\
\text { Forest } \\
\text { Service } \\
\text { land base }\end{array}$} & \multicolumn{4}{|c|}{ natural forest land } & \multicolumn{3}{|c|}{ plantdtion forest land } & \multirow[b]{2}{*}{$\begin{array}{l}\text { nonforest } \\
\text { land }\end{array}$} \\
\hline & & total & $\begin{array}{l}\text { closed } \\
\text { stands }\end{array}$ & $\begin{array}{l}\text { open } \\
\text { wood } \\
\text { lands }\end{array}$ & $\begin{array}{c}\text { unclosed } \\
\text { and dead } \\
\text { stands }\end{array}$ & total & $\begin{array}{l}\text { closed } \\
\text { stands }\end{array}$ & $\begin{array}{l}\text { unclosed } \\
\text { stands }\end{array}$ & \\
\hline 1 & 2 & 3 & 4 & 5 & 6 & 7 & 8 & 9 & 10 \\
\hline $\begin{array}{c}\text { Primorski krai, m.ha } \\
\%\end{array}$ & $\begin{array}{l}11.9 \\
100\end{array}$ & $\begin{array}{l}11.5 \\
97\end{array}$ & $\begin{array}{l}11.2 \\
94\end{array}$ & - & $\begin{array}{l}0.3 \\
3\end{array}$ & $\begin{array}{l}54.1^{1)} \\
0.5\end{array}$ & $\begin{array}{c}43.0^{1)} \\
0.4\end{array}$ & $\begin{array}{c}11.1^{1)} \\
0.1\end{array}$ & $\begin{array}{l}0.4 \\
3\end{array}$ \\
\hline $\begin{array}{c}\text { Khabarovski krai, m.ha } \\
\%\end{array}$ & $\begin{array}{l}73.9 \\
100\end{array}$ & $\begin{array}{l}57.4 \\
78\end{array}$ & $\begin{array}{l}47.2 \\
64\end{array}$ & $\begin{array}{l}2.4 \\
3\end{array}$ & $\begin{array}{c}7.8 \\
11\end{array}$ & $\begin{array}{c}192.5^{1)} \\
0.3\end{array}$ & $\begin{array}{c}107.9^{1)} \\
0.2\end{array}$ & $\begin{array}{c}84.6^{1)} \\
0.1\end{array}$ & $\begin{array}{l}16.3 \\
22\end{array}$ \\
\hline $\begin{array}{c}\text { Amurskaya oblast, m.ha } \\
\%\end{array}$ & $\begin{array}{l}30.7 \\
100\end{array}$ & $\begin{array}{l}25.3 \\
83\end{array}$ & $\begin{array}{l}21.7 \\
71\end{array}$ & $\begin{array}{l}0.6 \\
2\end{array}$ & $\begin{array}{l}3.0 \\
10\end{array}$ & $\begin{array}{l}95.1^{1)} \\
0.3\end{array}$ & $\begin{array}{c}57.9^{1)} \\
0.2\end{array}$ & $\begin{array}{c}40.6^{1)} \\
0.1\end{array}$ & $\begin{array}{l}5.3 \\
17\end{array}$ \\
\hline $\begin{array}{c}\text { Kamchatskaya oblast, m.ha } \\
\%\end{array}$ & $\begin{array}{l}15.0 \\
100\end{array}$ & $\begin{array}{l}9.4 \\
63\end{array}$ & $\begin{array}{c}8.9 \\
59\end{array}$ & $\begin{array}{l}0.3 \\
3\end{array}$ & $\begin{array}{l}0.2 \\
1\end{array}$ & $\begin{array}{l}66.4^{1)} \\
0.4\end{array}$ & $\begin{array}{l}35.1^{11} \\
0.2\end{array}$ & $\begin{array}{l}31.3^{\mathrm{i})} \\
0.2\end{array}$ & $\begin{array}{l}5.5 \\
37\end{array}$ \\
\hline $\begin{array}{c}\text { Magadanskaya oblast, m.ha } \\
\%\end{array}$ & $\begin{array}{l}71.7 \\
100\end{array}$ & $\begin{array}{l}37.0 \\
52\end{array}$ & $\begin{array}{l}22.0 \\
31\end{array}$ & $\begin{array}{c}9.7 \\
14\end{array}$ & $\begin{array}{l}5.3 \\
7\end{array}$ & $\begin{array}{r}25.5^{1)} \\
0.04\end{array}$ & $\begin{array}{l}4.7^{17} \\
0.007\end{array}$ & $\begin{array}{r}20.8^{1)} \\
0.03\end{array}$ & $\begin{array}{l}34.7 \\
48\end{array}$ \\
\hline $\begin{array}{c}\text { Sakhalinskaya oblast, m.ha } \\
\%\end{array}$ & $\begin{array}{c}6.9 \\
100\end{array}$ & $\begin{array}{l}6.0 \\
87\end{array}$ & $\begin{array}{ll}5.3 \\
78\end{array}$ & $\begin{array}{l}- \\
-\end{array}$ & $\begin{array}{l}0.7 \\
9\end{array}$ & $\begin{array}{c}199.6^{1)} \\
2.9\end{array}$ & $\begin{array}{c}141.7^{1)} \\
2.1\end{array}$ & $\begin{array}{c}57.9^{1)} \\
0.8^{1)}\end{array}$ & $\begin{array}{l}0.7 \\
10\end{array}$ \\
\hline $\begin{array}{c}\text { SAKhA Republic (Yakutia), } \\
\text { m.ha }\end{array}$ & 257.0 & 190.8 & 145.3 & 23.0 & 22.5 & $3.6^{1)}$ & $3.6^{1)}$ & - & 66.2 \\
\hline$\%$ & 100 & 74 & 56 & 9 & 9 & 0.001 & 0.001 & - & 26 \\
\hline $\begin{array}{c}\text { Jewish authonomous oblast, } \\
\text { m.ha }\end{array}$ & 2.2 & 1.7 & 1.6 & - & 0.1 & $38.3^{1)}$ & $20.1^{11}$ & $18.2^{1)}$ & 0.5 \\
\hline $\begin{array}{c}\% \\
\text { Korvakski authonomous }\end{array}$ & 100 & 76 & 72 & - & 4 & 2 & 1 & 1 & 22 \\
\hline $\begin{array}{c}\text { district, m.ha } \\
\%\end{array}$ & $\begin{array}{l}28.9 \\
100\end{array}$ & $\begin{array}{l}11.2 \\
39\end{array}$ & $\begin{array}{l}10.2 \\
35\end{array}$ & $\begin{array}{l}0.6 \\
2\end{array}$ & $\begin{array}{l}0.4 \\
2\end{array}$ & $\begin{array}{l}4.0^{1)} \\
0.01\end{array}$ & $\begin{array}{l}1.9^{1)} \\
0.006\end{array}$ & $\begin{array}{l}2.1^{1)} \\
0.007\end{array}$ & $\begin{array}{l}17.7 \\
61\end{array}$ \\
\hline $\begin{array}{c}\text { Far East, m.ha } \\
\%\end{array}$ & $\begin{array}{l}498.2 \\
100\end{array}$ & $\begin{array}{l}350.2 \\
70\end{array}$ & $\begin{array}{l}273.4 \\
55\end{array}$ & $\begin{array}{c}36.6 \\
7\end{array}$ & $\begin{array}{l}40.2 \\
8\end{array}$ & $\begin{array}{c}682.5^{1)} \\
0.1\end{array}$ & $\begin{array}{r}415.9^{11} \\
0.08\end{array}$ & $\begin{array}{r}266.6^{1)} \\
0.05\end{array}$ & $\begin{array}{c}147.3 \\
30\end{array}$ \\
\hline
\end{tabular}

1) thousand ha

Source: Data base of the Far East Forestry Research Institute, 1995

Primorski krai, dark coniferous forests of spruce (Picea) and fir (Abies) dominate. In Sakhalinskaya oblast and Primorski krai the area of dark coniferous forests is $55 \%$ and $48 \%$ of the coniferous stands, respectively In Primorski krai and Jewish autonomous oblast the area of Pinus koraiensis is relatively high - 34 and $33 \%$ respectively. Pinus koraiensis forests are the most valuable of the Far Eastern forests because of their diversity and unique flora and fauna. Although Pinus koraiensis is dominant in these stands, it is often only $30-40 \%$ of the timber volume. The rest of the timber volume in these stands is made up by many coniferous and broad-leaved species, with species accounting for 1 to $30 \%$ of the timber volume.

A significant portion of closed forests in the Far East is made up by old stands which are referred to as mature and overmature forests. The proportion of forest which are mature or overmature ranges from $63 \%$ in Koryakski autonomous district to $33 \% \mathrm{I}$ in Amurskaya oblast. The average for the Far East is $46 \%$ (Table 4 ). From the point of view of a standard clear harvesting system, such a proportion of mature stands is excessive. Among younger stands, the so called "average aged" ones prevail: for coniferousand broad-leaved stands with hardwood species these are stands from 41 to 80 years and for stands broadleaved species with soft wood, these are stands from 21 to 40 years old. The proportion of average aged stands is greatest in the closed forests of Kamchatskaya oblast (39\%) and least in Koryakski autonomous district (16\%). The average for the Far East is $27 \%$. Between the average aged and mature stands there are the so called "approaching maturity" stands which are aged 20 for coniferous and hard broad-leaved species or 10 for soft broad-leaved species. These stand are available for logging according the acting Rules of Harvesting in the forests of the Far East (Timber Harvesting Rules,1993). The proportion of "approaching maturity" stands is greatest in the closed forests of Koryakski autonomous district $(21 \%)$, and least in Kamchatskaya oblast and SAKhA Republic (Yakutia) (6\% in each), The average for the Far East is $9 \%$.

The rest of the closed forests are young and they account for between 1\% (forests of Koryakski autonomous district) and 24\% (both Amurskaya and Sakhalinskaya 
Table 3 Dominant species of the closed forests of each district of the Russian Far East

\begin{tabular}{|c|c|c|c|c|c|c|c|c|c|c|c|}
\hline \multirow{4}{*}{ Territorial units } & \multirow{4}{*}{$\begin{array}{l}\text { Total } \\
\text { closed } \\
\text { stands }\end{array}$} & \multicolumn{9}{|c|}{ Closed stands of the Russian Federal Forest Service } & \multirow{4}{*}{$\begin{array}{c}\text { brush } \\
\text { thickets }\end{array}$} \\
\hline & & \multicolumn{5}{|c|}{ coniferous stands } & \multicolumn{4}{|c|}{ deciduous stands } & \\
\hline & & \multirow[b]{2}{*}{ total } & \multicolumn{2}{|l|}{ Pine } & \multirow[b]{2}{*}{$\begin{array}{l}\text { spruce, } \\
\text { fir }\end{array}$} & \multirow[b]{2}{*}{ larch } & \multirow[b]{2}{*}{ total } & \multirow[b]{2}{*}{ oak } & \multirow[b]{2}{*}{ birch } & \multirow[b]{2}{*}{ other } & \\
\hline & & & $\begin{array}{l}\text { koraiensis, } \\
\text { sibirica }\end{array}$ & other & & & & & & & \\
\hline 1 & 2 & 3 & 4 & 5 & 6 & 7 & 8 & 9 & 10 & 11 & 12 \\
\hline $\begin{array}{c}\text { Primorski krai, m.ha } \\
\%\end{array}$ & $\begin{array}{l}11.2 \\
100\end{array}$ & $\begin{array}{l}6.5 \\
58\end{array}$ & 20 & $\begin{array}{l}\text { 1) } \\
\text { 2) }\end{array}$ & $\begin{array}{l}3.1 \\
27\end{array}$ & $\begin{array}{l}1.2 \\
11\end{array}$ & $\begin{array}{l}4.7 \\
42\end{array}$ & $\begin{array}{l}1.9 \\
17\end{array}$ & 15 & $\begin{array}{l}1.1 \\
10\end{array}$ & $\begin{array}{l}\text { 1) } \\
\text { 2) }\end{array}$ \\
\hline $\begin{array}{c}\text { Khabarovski krai, m.ha } \\
\%\end{array}$ & $\begin{array}{l}47.3 \\
100\end{array}$ & $\begin{array}{l}35.4 \\
75\end{array}$ & $\begin{array}{l}0.6 \\
1\end{array}$ & $\begin{array}{l}1.1 \\
3\end{array}$ & $\begin{array}{l}8.5 \\
18\end{array}$ & $\begin{array}{l}25.2 \\
53\end{array}$ & $\begin{array}{l}6.3 \\
13\end{array}$ & $\begin{array}{l}0.3 \\
1\end{array}$ & $\begin{array}{l}4.4 \\
9\end{array}$ & $\begin{array}{l}1.6 \\
3\end{array}$ & $\begin{array}{l}5.6 \\
12\end{array}$ \\
\hline $\begin{array}{c}\text { Amurskaya oblast, m.ha } \\
\%\end{array}$ & $\begin{array}{l}21.8 \\
100\end{array}$ & $\begin{array}{l}14.4 \\
66\end{array}$ & $\begin{array}{l}\text { 1) } \\
\text { 2) }\end{array}$ & $\begin{array}{l}0.7 \\
3\end{array}$ & $\begin{array}{l}0.5 \\
2\end{array}$ & $\begin{array}{l}13.2 \\
61\end{array}$ & $\begin{array}{l}5.3 \\
24\end{array}$ & $\begin{array}{l}0.4 \\
2\end{array}$ & $\begin{array}{l}4.7 \\
21\end{array}$ & $\begin{array}{l}0.2 \\
1\end{array}$ & $\begin{array}{l}2.1 \\
10\end{array}$ \\
\hline $\begin{array}{c}\text { Kamchatskaya oblast, m.ha } \\
\%\end{array}$ & $\begin{array}{r}8.9 \\
100\end{array}$ & $\begin{array}{l}0.7 \\
8\end{array}$ & - & $\begin{array}{l}\text { 1) } \\
\text { 2) }\end{array}$ & $\begin{array}{l}0.2 \\
2\end{array}$ & $\begin{array}{l}0.5 \\
6\end{array}$ & $\begin{array}{l}5.7 \\
64\end{array}$ & $\begin{array}{l}- \\
-\end{array}$ & $\begin{array}{l}4.5 \\
51\end{array}$ & $\begin{array}{l}1.2 \\
13\end{array}$ & $\begin{array}{l}2.5 \\
28\end{array}$ \\
\hline $\begin{array}{c}\text { Magadanskaya oblast, m.ha } \\
\%\end{array}$ & $\begin{array}{l}22.0 \\
100\end{array}$ & $\begin{array}{l}9.4 \\
43\end{array}$ & $\begin{array}{l}- \\
-\end{array}$ & $\begin{array}{l}\text { 1) } \\
\text { 2) }\end{array}$ & $\begin{array}{l}- \\
-\end{array}$ & $\begin{array}{l}9.4 \\
43\end{array}$ & $\begin{array}{l}0.3 \\
1\end{array}$ & $\begin{array}{l}- \\
-\end{array}$ & $\begin{array}{l}\text { 1) } \\
\text { 2) }\end{array}$ & $\begin{array}{l}0.3 \\
1\end{array}$ & $\begin{array}{l}12.3 \\
56\end{array}$ \\
\hline Sakhalinskaya oblast, m.ha & 5.4 & 3.8 & $\begin{array}{l}\text { 1) } \\
\text { 2) }\end{array}$ & 0.1 & 2.1 & 1.6 & 1.3 & 0.1 & 1.1 & 0.1 & 0.3 \\
\hline $\begin{array}{c}\% \\
\text { SAKhA Republic (Yakutia), } \\
\text { m.ha }\end{array}$ & 145.3 & 125.8 & 0. & 10.0 & 39 & 115.0 & 24 & 2 & 1.9 & 2 & 17.5 \\
\hline$\%$ & 100 & 87 & 1 & 7 & 2) & 79 & 1 & - & 1.0 & 0. & 12 \\
\hline $\begin{array}{c}\text { Jewish authonomous oblast, } \\
\text { m.ha }\end{array}$ & 1.6 & 0.6 & 0.2 & 1) & 0.2 & 0.2 & 1.0 & 0.4 & 0.4 & 0.2 & 1) \\
\hline$\%$ & 100 & & 13 & 2) & 12 & 12 & & 25 & & & 2) \\
\hline $\begin{array}{c}\text { Koryakski authonomous } \\
\text { district, m.ha } \\
\%\end{array}$ & $\begin{array}{l}102.2 \\
100\end{array}$ & $\begin{array}{l}0.4 \\
4\end{array}$ & $\begin{array}{l}- \\
-\end{array}$ & $\begin{array}{l}- \\
-\end{array}$ & $\begin{array}{l}- \\
-\end{array}$ & $\begin{array}{l}0.4 \\
4\end{array}$ & 23 & - & $\begin{array}{l}2.1 \\
20\end{array}$ & $\begin{array}{l}0.3 \\
3\end{array}$ & $\begin{array}{l}7.4 \\
73\end{array}$ \\
\hline $\begin{array}{c}\text { Far East, m.ha } \\
\%\end{array}$ & $\begin{array}{l}273.7 \\
100\end{array}$ & $\begin{array}{l}197.0 \\
72\end{array}$ & $\begin{array}{l}3.4 \\
1\end{array}$ & $\begin{array}{c}11.9 \\
4\end{array}$ & $\begin{array}{c}15.0 \\
5\end{array}$ & $\begin{array}{c}166.7 \\
61\end{array}$ & $\begin{array}{l}29.0 \\
11\end{array}$ & $\begin{array}{l}3.1 \\
1\end{array}$ & $\begin{array}{c}10.8 \\
8\end{array}$ & $\begin{array}{l}5.1 \\
2\end{array}$ & $\begin{array}{l}47.7 \\
17\end{array}$ \\
\hline
\end{tabular}

1) less than $0.05 \mathrm{~m} . \mathrm{ha}$

2) less than $0.5 \%$

Source: Data base of the Far East Forestry Research Institute, 1995

oblasts). From the point of view of a standard clear harvesting system, the age structure of the forests in the Far East is far from perfection. From the point of view of environmental protection, the forests age structure is also not perfect because the environment is better protected by climax forests. Hence an age structure analysis would be useful for concrete economic analysis of the forests, however, this is not the purpose of this article.

The Far East forests are of low productivity because of the severe natural conditions. Average yields of mature stands and shrub thickets range from 14 to $278 \mathrm{cu} . \mathrm{m} / \mathrm{ha}$ (Table 5). There is no clear pattern of increased productivity from North to South, and the productivity of coniferous stands is not always higher than that of broad-leaved stands. Mountainous topography, significantly differing climatic conditions, uneven bedding, thickness of permafrost and other natural conditions result in a wide variation in forest productivity without any clear spatial trends.

Pinus koraiensis (Pinus sibirica) stands are the most productive formation, except in Amurskaya oblast where timber productivity is higher from fir and poplar stands, and SAKhA Republic (Yakutia) fir stands. Generally,dark coniferous stands spruce and fir are inferior in productivity only to Pinus koraiensis forests, except in Khabarovski krai where dark coniferous stands are outstripped by poplar stands. The productivity of mature larch stands is often lower than that of broad-leaved stands. Data in Table 1 briefly characterizes the pattern of productivity in the Far East forests. There is a mosaic of productivity classes across territorial units which is even stronger within smaller regions.

In spite of the low productivity of the Far East forests, the total timber yield is significant ( 20.5 bill.cu.m., Table 6$)$. The yield of coniferous stands $(83 \%)$ is large than the area they represent $(72 \%)$. This means that the overall productivity of the coniferous stands is higher than that of the rest of the closed forests.

High yields of nontimber resources, such as medicinal 
Table 4 Age class distributions of the closed forests of each district of the Russian Far East

\begin{tabular}{|c|c|c|c|c|c|c|}
\hline \multirow{3}{*}{ Territorial units } & \multicolumn{6}{|c|}{ Closed stands of the Russian Federal Forest Service } \\
\hline & \multirow{2}{*}{$\begin{array}{l}\text { Total } \\
\text { closed } \\
\text { stands }\end{array}$} & \multicolumn{2}{|c|}{ Young stands } & \multirow{2}{*}{$\begin{array}{c}\text { average } \\
\text { aged } \\
\text { stands }\end{array}$} & \multirow{2}{*}{$\begin{array}{c}\text { approaching } \\
\text { maturity } \\
\text { stands }\end{array}$} & \multirow{2}{*}{$\begin{array}{l}\text { mature } \\
\text { stands }\end{array}$} \\
\hline & & $\begin{array}{l}\text { the } 1 \text { st } \\
\text { age class }\end{array}$ & $\begin{array}{l}\text { the } 2 \text { nd } \\
\text { age class }\end{array}$ & & & \\
\hline 1 & 2 & 3 & 4 & 5 & 6 & 7 \\
\hline $\begin{array}{c}\text { Primorski krai, m.ha } \\
\%\end{array}$ & $\begin{array}{l}11.2 \\
100\end{array}$ & $\begin{array}{l}0.2 \\
2\end{array}$ & $\begin{array}{l}0.5 \\
4\end{array}$ & $\begin{array}{l}4.1 \\
37\end{array}$ & $\begin{array}{l}1.7 \\
15\end{array}$ & $\begin{array}{l}4.7 \\
42\end{array}$ \\
\hline $\begin{array}{c}\text { Khabarovski krai, m.ha } \\
\%\end{array}$ & $\begin{array}{l}47.3 \\
100\end{array}$ & $\begin{array}{l}3.7 \\
8\end{array}$ & $\begin{array}{l}4.5 \\
9\end{array}$ & $\begin{array}{l}12.7 \\
27\end{array}$ & $\begin{array}{l}4.7 \\
10\end{array}$ & $\begin{array}{l}21.7 \\
46\end{array}$ \\
\hline $\begin{array}{c}\text { Amurskaya oblast, m.ha } \\
\%\end{array}$ & $\begin{array}{l}21.8 \\
100\end{array}$ & $\begin{array}{l}2.3 \\
11\end{array}$ & $\begin{array}{l}2.9 \\
13\end{array}$ & 32 & $\begin{array}{c}2.3 \\
11\end{array}$ & $\begin{array}{l}7.3 \\
33\end{array}$ \\
\hline $\begin{array}{c}\text { Kamchatskaya oblast, m.ha } \\
\%\end{array}$ & $\begin{array}{c}8.9 \\
100\end{array}$ & $\begin{array}{l}0.1 \\
1\end{array}$ & $\begin{array}{l}0.1 \\
1\end{array}$ & $\begin{array}{l}3.5 \\
39\end{array}$ & $\begin{array}{l}0.5 \\
6\end{array}$ & $\begin{array}{l}4.7 \\
53\end{array}$ \\
\hline $\begin{array}{c}\text { Magadanskaya oblast, m.ha } \\
\%\end{array}$ & $\begin{array}{l}22.0 \\
100\end{array}$ & $\begin{array}{l}1.0 \\
5\end{array}$ & $\begin{array}{l}2.2 \\
10\end{array}$ & $\begin{array}{l}5.7 \\
26\end{array}$ & $\begin{array}{l}3.4 \\
15\end{array}$ & $\begin{array}{c}9.7 \\
44\end{array}$ \\
\hline $\begin{array}{c}\text { Sakhalinskaya oblast, m.ha } \\
\%\end{array}$ & $\begin{array}{ll}5.4 \\
100\end{array}$ & $\begin{array}{l}0.4 \\
7\end{array}$ & $\begin{array}{l}0.9 \\
17\end{array}$ & $\begin{array}{l}1.6 \\
30\end{array}$ & $\begin{array}{l}0.5 \\
9\end{array}$ & $\begin{array}{l}2.0 \\
37\end{array}$ \\
\hline $\begin{array}{c}\text { SAKhA Republic (Yakutia), m.ha } \\
\%\end{array}$ & $\begin{array}{l}145.3 \\
100\end{array}$ & $\begin{array}{l}14.4 \\
10\end{array}$ & $\begin{array}{l}14.9 \\
10\end{array}$ & $\begin{array}{l}38.2 \\
27\end{array}$ & $\begin{array}{l}9.1 \\
6\end{array}$ & $\begin{array}{l}68.7 \\
47\end{array}$ \\
\hline $\begin{array}{c}\text { Jewish authonomous oblast, m.ha } \\
\%\end{array}$ & 100 & $\begin{array}{l}0.1 \\
6\end{array}$ & $\begin{array}{l}0.2 \\
13\end{array}$ & 0.5 & $\begin{array}{l}0.2 \\
13\end{array}$ & $\begin{array}{l}0.6 \\
37\end{array}$ \\
\hline $\begin{array}{c}\text { Koryakski authonomous district, m.ha } \\
\%\end{array}$ & $\begin{array}{c}10.2 \\
100\end{array}$ & $\begin{array}{l}\text { 1) } \\
\text { 2) }\end{array}$ & 1) & 1.6 & 2.2 & $\begin{array}{l}6.4 \\
63\end{array}$ \\
\hline $\begin{array}{c}\text { Far East, m.ha } \\
\%\end{array}$ & $\begin{array}{l}273.7 \\
100\end{array}$ & 22.2 & $\begin{array}{l}26.2 \\
10\end{array}$ & $\begin{array}{l}74.9 \\
27\end{array}$ & $\begin{array}{c}24.6 \\
9\end{array}$ & $\begin{array}{c}125.8 \\
46\end{array}$ \\
\hline
\end{tabular}

1) less than $0.05 \mathrm{~m} \cdot \mathrm{ha}$

2) less than $0.5 \%$

Source: Data base of the Far East Forestry Research Institute, 1995

Table 5 Average yield $\left(\mathrm{m}^{3} / \mathrm{ha}\right)$ of standing timber in mature stands of dominant species in the Russian Far East

\begin{tabular}{|c|c|c|c|c|c|c|c|c|c|c|c|c|}
\hline \multirow{3}{*}{$\begin{array}{l}\text { Territorial } \\
\text { units }\end{array}$} & \multicolumn{12}{|c|}{ Forest Service land base of Federal Forest Service } \\
\hline & \multicolumn{5}{|c|}{ coniferous } & \multicolumn{6}{|c|}{ broadleaved } & \multirow{2}{*}{$\begin{array}{l}\text { Pinus } \\
\text { pumila }\end{array}$} \\
\hline & $\begin{array}{c}\text { Pinus } \\
\text { koraiensis }\end{array}$ & $\begin{array}{l}\text { Pine } \\
\text { (Pinus) }\end{array}$ & $\begin{array}{l}\text { Spruce } \\
(\text { Picea })\end{array}$ & $\begin{array}{c}\text { Fir } \\
\text { (Abies) }\end{array}$ & $\begin{array}{l}\text { Larch } \\
(\text { Larix })\end{array}$ & $\begin{array}{c}\text { Oak } \\
\text { Quercus })\end{array}$ & $\begin{array}{c}\text { Ash } \\
\text { Fraxinus })\end{array}$ & $\begin{array}{l}\text { Hardwood } \\
\text { birches }\end{array}$ & $\begin{array}{l}\text { Softwood } \\
\text { birches }\end{array}$ & $\begin{array}{c}\text { Linden } \\
\text { (Tilia) }\end{array}$ & $\begin{array}{c}\text { Poplar } \\
(\text { Populus })\end{array}$ & \\
\hline 1 & 2 & 3 & 4 & 5 & 6 & 7 & 8 & 9 & 10 & 11 & 12 & 13 \\
\hline Primorski krai & 250 & 112 & 200 & 179 & 190 & 131 & 140 & 170 & 146 & 160 & 178 & 62 \\
\hline Khabarovski krai & 278 & 140 & 188 & 169 & 129 & 111 & 138 & 160 & 129 & 152 & 200 & 24 \\
\hline Amurskaya oblast & 193 & 124 & 183 & 212 & 129 & 59 & - & - & 129 & 131 & 210 & 62 \\
\hline Kamchatskaya ob. & - & - & 193 & - & 167 & - & - & 85 & 91 & - & 167 & 75 \\
\hline Magadanskaya ob. & - & & - & - & 53 & - & - & - & 45 & - & 155 & 15 \\
\hline Sakhalinskaya ob. & - & - & 210 & 229 & 155 & 114 & - & 73 & 91 & - & 141 & 56 \\
\hline $\begin{array}{l}\text { SAKhA Republic } \\
\text { (Yakutia) }\end{array}$ & $181^{*}$ & 132 & 134 & 190 & 86 & - & - & - & 100 & - & 130 & 14 \\
\hline $\begin{array}{l}\text { Jewish authonomous } \\
\text { obl. }\end{array}$ & 202 & - & 177 & 167 & 150 & 100 & 125 & 169 & 120 & 163 & 133 & - \\
\hline $\begin{array}{l}\text { Koryakski autho- } \\
\text { nomous district }\end{array}$ & - & & - & - & 48 & - & - & 92 & 70 & - & 105 & 62 \\
\hline
\end{tabular}

* Pinus sibirica

Source: Data base of the Far East Forestry Research Institute, 1995 
Table 6 Species composition of the closed stands in each district of the Russian Far East

\begin{tabular}{|c|c|c|c|c|c|c|c|c|c|c|c|}
\hline \multirow{4}{*}{ Territorial units } & \multicolumn{10}{|c|}{ Closed stands of the Russian Federal Forest Service } & \multirow{4}{*}{$\begin{array}{l}\text { brush } \\
\text { thickets }\end{array}$} \\
\hline & \multirow{3}{*}{$\begin{array}{c}\text { Total } \\
\text { closed } \\
\text { stands }\end{array}$} & \multicolumn{5}{|c|}{ coniferous stands } & \multicolumn{4}{|c|}{ deciduous stands } & \\
\hline & & \multirow[b]{2}{*}{ total } & \multicolumn{2}{|l|}{ Pine } & \multirow[b]{2}{*}{$\begin{array}{l}\text { spruce, } \\
\text { fir }\end{array}$} & \multirow[b]{2}{*}{ larch } & \multirow[b]{2}{*}{ total } & \multirow[b]{2}{*}{ oak } & \multirow[b]{2}{*}{ birch } & \multirow[b]{2}{*}{ other } & \\
\hline & & & $\begin{array}{l}\text { koraiensis, } \\
\text { sibirica }\end{array}$ & other & & & & & & & \\
\hline 1 & 2 & 3 & 4 & 5 & 6 & 7 & 8 & 9 & 10 & 11 & 12 \\
\hline $\begin{array}{c}\text { Primorski krai, bill.cu.m. } \\
\%\end{array}$ & 100 & $\begin{array}{l}1.2 \\
67\end{array}$ & $\begin{array}{l}0.5 \\
28\end{array}$ & $\begin{array}{l}\text { 1) } \\
\text { 2) }\end{array}$ & $\begin{array}{l}0.5 \\
28\end{array}$ & $\begin{array}{c}0.2 \\
11\end{array}$ & $\begin{array}{l}0.6 \\
33\end{array}$ & $\begin{array}{l}0.2 \\
11\end{array}$ & 0.2 & $\begin{array}{c}0.2 \\
11\end{array}$ & $\begin{array}{l}\text { 1) } \\
\text { 2) }\end{array}$ \\
\hline $\begin{array}{c}\text { Khabarovski krai, bill.cu.m. } \\
\%\end{array}$ & $\begin{array}{l}5.0 \\
100\end{array}$ & $\begin{array}{l}4.3 \\
86\end{array}$ & $\begin{array}{l}0.1 \\
2\end{array}$ & $\begin{array}{l}0.1 \\
2\end{array}$ & 1.5 & $\begin{array}{l}2.6 \\
52\end{array}$ & $\begin{array}{l}0.5 \\
10\end{array}$ & $\begin{array}{l}\text { 1) } \\
\text { 2) }\end{array}$ & $\begin{array}{l}0.3 \\
6\end{array}$ & $\begin{array}{l}0.2 \\
4\end{array}$ & $\begin{array}{l}0.2 \\
4\end{array}$ \\
\hline $\begin{array}{c}\text { Amurskaya oblast, bill.cu.m. } \\
\%\end{array}$ & $\begin{array}{l}2.0 \\
100\end{array}$ & $\begin{array}{l}1.6 \\
80\end{array}$ & $\begin{array}{l}\text { 1) } \\
\text { 2) }\end{array}$ & $\begin{array}{l}0.1 \\
5\end{array}$ & $\begin{array}{l}0.1 \\
5\end{array}$ & $\begin{array}{l}1.4 \\
70\end{array}$ & 0.3 & $\begin{array}{l}\text { 1) } \\
\text { 2) }\end{array}$ & $\begin{array}{ll}0.3 \\
15\end{array}$ & $\begin{array}{l}\text { 1) } \\
\text { 2) }\end{array}$ & $\begin{array}{l}0.1 \\
5\end{array}$ \\
\hline $\begin{array}{c}\text { Kamchatskaya oblast, bill.cu. } \\
\text { m. }\end{array}$ & 0.6 & 0.1 & - & 1) & 1) & 0.1 & 0.4 & - & 0.4 & 1) & 0.1 \\
\hline$\%$ & 100 & 17 & - & 2) & 2) & 17 & 67 & - & 67 & 2) & 16 \\
\hline $\begin{array}{c}\text { Magadanskaya oblast, bill.cu. } \\
\mathrm{m} .\end{array}$ & 0.5 & 0.3 & - & 1) & - & 0.3 & 1) & - & 1) & 1) & 0.2 \\
\hline$\%$ & 100 & 60 & - & 2) & - & 60 & 2) & - & 2) & 2) & 40 \\
\hline $\begin{array}{c}\text { Sakhalinskaya oblast, bill.cu. } \\
\mathrm{m} .\end{array}$ & 0.6 & 0.5 & - & 1) & 0.4 & 0.1 & 0.1 & 1) & 0.1 & 1) & 1) \\
\hline$\%$ & 100 & 83 & - & 2) & 67 & 16 & 17 & 2) & 17 & 2) & 2) \\
\hline $\begin{array}{l}\text { SAKhA Republic(Yakutia), } \\
\text { bill.cu.m. }\end{array}$ & 9.2 & 8.9 & 0.1 & 1.0 & 1) & 7.8 & 0.1 & - & 0.1 & 1) & 0.2 \\
\hline$\%$ & 100 & 97 & 1 & 11 & 2) & 85 & 1 & - & 1 & 2) & 2 \\
\hline $\begin{array}{l}\text { Jewish authonomous oblast, } \\
\text { bill.cu.m. }\end{array}$ & 0.2 & 0.1 & 1) & 1) & 0.1 & 1) & 0.1 & 1) & 1) & 0.1 & 1) \\
\hline$\%$ & 100 & 50 & 15 & 2) & 25 & 10 & 50 & 15 & 15 & 20 & 2) \\
\hline $\begin{array}{c}\text { Koryakski authonomous } \\
\text { district, bill.cu.m. } \\
\%\end{array}$ & $\begin{array}{l}0.6 \\
100\end{array}$ & $\begin{array}{l}\text { 1) } \\
\text { 2) }\end{array}$ & $\begin{array}{l}- \\
-\end{array}$ & 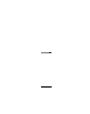 & $\begin{array}{l}- \\
-\end{array}$ & $\begin{array}{l}\text { 1) } \\
\text { 2) }\end{array}$ & $\begin{array}{l}0.2 \\
33\end{array}$ & $\begin{array}{l}- \\
-\end{array}$ & $\begin{array}{l}0.2 \\
33\end{array}$ & $\begin{array}{l}\text { 1) } \\
\text { 2) }\end{array}$ & $\begin{array}{l}0.4 \\
67\end{array}$ \\
\hline $\begin{array}{c}\text { Far East, bill.cu.m. } \\
\%\end{array}$ & $\begin{array}{l}20.5 \\
100\end{array}$ & $\begin{array}{l}17.0 \\
83\end{array}$ & $\begin{array}{l}0.7 \\
3\end{array}$ & $\begin{array}{l}1.2 \\
6\end{array}$ & $\begin{array}{l}2.6 \\
13\end{array}$ & $\begin{array}{l}12.5 \\
61\end{array}$ & 11 & $\begin{array}{l}0.3 \\
1\end{array}$ & $\begin{array}{l}1.6 \\
8\end{array}$ & $\begin{array}{l}0.4 \\
2\end{array}$ & $\begin{array}{l}1.2 \\
6\end{array}$ \\
\hline
\end{tabular}

1) less than 0.05 bill.cu.m.

2) less than $0.5 \%$

Source: Data base of the Far East Forestry Research Institute, 1995

plants, food items and a rich and diverse fauna are found in the Far East forests (Sukhomirov 1984). All these riches are provided by the Forest Service land base. The opportunities of multipurpose forest use depend on the condition of the Forest Service land base.

At the moment it is impossible to evaluate the condition of the Far East forests from the current inventory data, because one cannot evaluate it as bad or good. It is obviously bad that there is a lot of waste nonproductive land (burnt, logged or other areas). It is also bad that the sites of former original stands are behind reproduced by secondary species of lower value (broad-leaved, shrubs and other). However the forest area yields of timber and nontimber resources are still very high and sufficient, or in some cases even too much, for various needs. Hence it is impossible to describe the forests condition only as bad.

Yet it is obvious that the condition of the forests worsened when the share of low producing tracts increased. To evaluate the forests condition meaningfully,the dynamics most be evaluated, and the probability of critical situations occurring must be predicted.

\section{Forest Dynamics}

Forest use can be divided into 3 categories: raw resources, social and ecological uses. In the 1950s and 1960 $\mathrm{s}$, the main use of forests was as a raw resource, but now ecological uses have become important.

It is important to understand the dynamics of the forests if the ecological value of the forests is to be evaluated. Thus, it is important to know the forest area and to evaluate how it has changed either quantitatively or qualitatively.

The area of forest can be evaluated relative to the

\section{J. For. Plann. 3:31-40 (1997)}


total area of the region,i.e. "area under forest". There exist various classifications of area under forest. According to one of them, developed for Russia conditions (TzEPLYAEV 1965)), sites with less than $2 \%$ of the area under forest are regarded as forestless; $2-15 \%$ are sparsely forested; $16-30 \%$ are averagely forested; $31-45 \%$ are forested and sites with $45 \%$ are heavily forested. According to this classification, Magadanskaya oblast is averagely forested, Kamchatskaya oblast is forested and the rest of the territorial units of the Far East are heavily forested (Table 7). From here, data for Khabarovski krai are and Jewish autonomous oblast, and data for Kamchatskaya oblast and Koryakski autonomous district are combined.

During the 27 years from 1966 to 1993 the area under forest increased in all districts. From an ecological standpoint, such dynamics should be regarded as positive. It's reasonable to assume that the area under forest increased because of natural forest reproduction and reduced losses from fires in Forest Service land base.

The area under forest cannot grow endlessly. The potential for growth is in the nonclosed and dead forests. The area of such forest in Khabarovski krai, Amurskaya and Sakhalinskaya oblasts suggests that area under forest of these districts could reach the same levels as level of Primorski krai and SAKhA Republic (Yakutia) (55\%). In Kamchatskaya and Magadanskaya oblasts (forested and averagely forested respectively, the area under forest should not change.

The area under forest should be regulated according to economic expediency. A purposeful reduction of area under forest in the future could be justified as an attempt to satisfy optimum area under forest criteria. In the Russian forest zone, the optimum area under forest was found to be between 50-55\% (ShEINGAUZ 1978, TARASENKo 1976, ZhiLTzov 1989, etc.). This criterion is suitable for Primorski krai, Khabarovski krai, Amurskaya krai and Sakhalinskaya oblast and forest area should not be decreased below

Table 7 Changes in forest area (percentage of forest area which is closed stands) for each district, 1966-93.

\begin{tabular}{|l|c|c|c|c|c|c|}
\hline \multicolumn{1}{c}{ Territorial } & \multicolumn{6}{|c|}{ years } \\
\cline { 2 - 7 } \multicolumn{1}{c|}{} & 1966 & 1973 & 1978 & 1983 & 1988 & 1993 \\
\hline Primorski krai & 74 & 74 & 72 & 73 & 75 & 77 \\
Khabarovski krai & 52 & 52 & 51 & 55 & 60 & 61 \\
Amurskaya oblast & 55 & 56 & 56 & 61 & 62 & 62 \\
Kamchatskaya oblast & 40 & 40 & 41 & 42 & 42 & 42 \\
Magadanskaya oblast & 18 & 17 & 15 & 15 & 19 & 19 \\
Sakhalinskaya oblast & 55 & 59 & 57 & 63 & 64 & 65 \\
SAKhA Republic & 38 & 42 & 46 & 48 & 47 & 47 \\
\hline Far East & 39 & 41 & 41 & 43 & 45 & 45 \\
\hline
\end{tabular}

Source: Data base of the Far East Forestry Research Institute, 1995. this level. In Kamchatskaya and Magaanskaya oblasts and SAKhA Republic (Yakutia), such criteria still need to be developed.

Although area under forest is an index used to describe the of ecological protectiveness of an area, it doesn't measure the degree of such protectiveness and is only a reference point for such a purpose. The effectiveness of forests in environmental protection is influenced not only by their total area but also by the structure of vegetation. Ecological functions are better achieved by virgin forests in climax condition with a high canopy density. Replacement of the original species with secondary ones, and decreases in age or density cause the environment at protection to weaken.

To evaluate the species composition dynamics, we used conventional points of dominating species (SHEINGAUZ 1986). Points sums ratios for different years in the Forest

Table 8 Changes in the species composition of the Far East forests, 1966-93.

\begin{tabular}{|l|l|l|l|l|l|l|}
\hline \multicolumn{9}{|c|}{ years } \\
\hline Territorial units & $1966-$ & $1973-$ & $1978-$ & 1983 & $1988-$ & $1966-$ \\
& 1972 & 1977 & 1982 & 1987 & 1992 & 1992 \\
\hline Primorski krai & 0.99 & 0.98 & 1.00 & 1.04 & 0.99 & 1.01 \\
Khabarovski krai & 0.98 & 0.99 & 0.98 & 1.02 & 0.91 & 0.89 \\
Amurskaya oblast & 0.98 & 0.99 & 1.00 & 0.97 & 0.93 & 0.92 \\
Kamchatskaya ob. & 1.00 & 1.00 & 0.98 & 0.85 & 0.89 & 0.75 \\
Magadanskaya ob. & 0.99 & 1.00 & 1.00 & 0.91 & 1.00 & 0.90 \\
Sakhalinskaya ob. & 1.00 & 1.00 & 1.00 & 0.99 & 0.99 & 0.99 \\
SAKhA Republic & 1.00 & 1.00 & 0.96 & 0.98 & 1.00 & 0.94 \\
(Yakutia) & & & & & & \\
\hline
\end{tabular}

Unit is times. Each numeral shows how to times each year composition changing next term.

Source: Data base of the Far East Forestry Research Institute, 1995.

Table 9 Changes in age structure of the Far East forests, $1966-93$.

\begin{tabular}{|l|l|l|l|l|l|l|}
\hline \multicolumn{10}{|c|}{ years } \\
\hline Territorial units & $1966^{-}$ & $1973^{-}$ & $1978^{-}$ & $1983^{-}$ & $1988^{-}$ & $1966^{-}$ \\
\hline Primorski krai & 1972 & 1977 & 1982 & 1987 & 1992 & 1992 \\
\hline Khabarovski krai & 0.96 & 0.98 & 0.96 & 0.99 & 0.96 & 0.86 \\
Amurskaya oblast & 0.87 & 0.98 & 0.96 & 0.96 & 0.98 & 0.87 \\
Kamchatskaya ob. & 0.98 & 0.94 & 0.98 & 0.99 & 0.99 & 0.82 \\
Magadanskaya ob. & 1.01 & 0.88 & 1.00 & 0.91 & 1.00 & 0.80 \\
Sakhalinskaya ob. & 0.96 & 0.98 & 0.91 & 0.98 & 0.97 & 0.82 \\
SAKhA Republic & 0.96 & 0.98 & 0.98 & 0.96 & 0.99 & 0.89 \\
(Yakutia) & & & & & & \\
\hline
\end{tabular}

This table was calculated in the same way as table 8 .

Source: Data base of the Far East Forestry Research Institute, 1995 
Service land base inventory gives a coefficient of species composition dynamics between the years (Table 8 ). The species composition was constantly getting poorer. The greatest changes were in Kamchatskaya oblast where species with high scores, decreased and species with low scores increased.

Conventional points were also used to analyze forest cover age structure dynamics (SheINGAUZ 1986). Mature stands are rated higher and young stands lower. Age structure change rates were higher than changes in species composition and more uniform (negative, Table 9) .

To analyze canopy density dynamics we used, for lack of a better index, the average yield of timber per ha of forest covered land. Changes in average timber yield between different years in the Forest Service land base inventory were evaluated by their ratio and measured by coefficients (Table 10). The average yield dynamics were chaotic, but this analysis helped us understand forest cover quality dynamics.

The average arithmetical value of the coefficients in Tables 8-10 integrate the changes in forest cover quality (Table 11). Generally, the trends are negative, but without clear criteria it is impossible to evaluate accurately the current qualitative condition of the forests. Even in Magadanskaya oblast where the quality coefficient decreased by $25 \%$ over 23 years, it is impossible to make a conclusion about the quality of the forest. However, from an ecological standpoint, reduction in forest quality should be regarded as undesirable and should prompt action to regulate the forests.

From a timber production stand point, trends in operational forests are important. Currently in Russia all mature and overmature stands are regarded as operational forests excluding the stands which are not logged for ecological, economic or other reasons (GoskomLES USSR 1991). The most important operational forests of the Far

Table 10 Changes in average timber yields of the forest lands of the Russian Far East, 1966-93.

\begin{tabular}{|c|c|c|c|c|c|c|}
\hline & \multicolumn{6}{|c|}{ years } \\
\hline Territorial units & $\begin{array}{l}1966^{-} \\
1972\end{array}$ & $\begin{array}{l}1973^{-} \\
1977\end{array}$ & $\begin{array}{l}1978- \\
1982\end{array}$ & $\begin{array}{l}1983^{-} \\
1987\end{array}$ & $\begin{array}{l}1988- \\
1992\end{array}$ & $\begin{array}{l}1966^{-} \\
1992\end{array}$ \\
\hline Primorski krai & 0.97 & 1.01 & 0.97 & 0.98 & 1.01 & 0.93 \\
\hline Khabarovski krai & 1.01 & 1.02 & 0.95 & 0.93 & 0.97 & 0.88 \\
\hline Amurskaya oblast & 0.84 & 1.02 & 1.00 & 0.99 & 0.98 & 0.83 \\
\hline Kamchatskaya ob. & 0.98 & 0.95 & 1.17 & 1.01 & 1.00 & 1.09 \\
\hline Magadanskaya ob. & 0.84 & 0.92 & 0.98 & 0.74 & 1.00 & 0.56 \\
\hline Sakhalinskaya ob. & 0.98 & 0.98 & 0.91 & 1.00 & 0.93 & 0.81 \\
\hline $\begin{array}{l}\text { SAKhA Republic } \\
\text { (Yakutia) }\end{array}$ & 0.93 & 0.94 & 0.91 & 0.91 & 1.00 & 0.74 \\
\hline
\end{tabular}

\section{J. For. Plann. 3:31-40 (1997)}

East are the coniferous stands. Even in Kamchatskaya oblast where the proportion of coniferous stands is low, mostly these stands are logged.

Changes in area of the mature coniferous stands were persistently negative (Table 12). The greatest changes occurred in Primorski krai. In 1966 the krai had the greatest operational potential but currently it is fifth. These changes were caused by intensive logging of Pinus koraiensis stands between 1960 and 1980 .

Despite these negative trends, the timber potential of mature coniferous stands in the Far East remains high. Excluding Kamchatskaya and Magadanskaya oblasts, the proportion of mature coniferous stands in all regions exceeds the theoretical level sufficient for continuous and inexhaustible use (17-20\%). The current annual allowable cut is less than half the potential in all regions including Kamchatskaya and Magadanskaya oblasts.

Table 11 Changes in the integrated quality index of forest cover in the Russian Far East, 1966-93.

\begin{tabular}{|l|l|l|l|l|l|l|}
\hline \multicolumn{10}{|c|}{ years } \\
\hline Territorial units & $1966^{-}$ & $1973-$ & $1978^{-}$ & $1983-$ & $1988^{-}$ & $1966^{-}$ \\
& 1972 & 1977 & 1982 & 1987 & 1992 & 1992 \\
\hline Primorski krai & 0.97 & 0.99 & 0.98 & 1.00 & 0.99 & 0.93 \\
Khabarovski krai & 0.99 & 1.00 & 0.96 & 0.97 & 0.95 & 0.88 \\
Amurskaya oblast & 0.90 & 1.00 & 0.99 & 0.98 & 0.97 & 0.86 \\
Kamchatskaya ob. & 0.99 & 0.96 & 1.01 & 0.95 & 0.87 & 0.81 \\
Magadanskaya ob. & 0.95 & 0.93 & 0.99 & 0.85 & 1.00 & 0.75 \\
Sakhalinskaya ob. & 0.98 & 0.99 & 0.94 & 0.99 & 0.96 & 0.87 \\
SAKhA Republic & 0.96 & 0.97 & 0.95 & 0.95 & 1.00 & 0.86 \\
(Yakutia) & & & & & & \\
\hline
\end{tabular}

These values are average arithmetical value of coefficients in table 8.9 .10

For example; 1996-1972: Table $8=0.94$; Table $9=0.99$; Table $10=0.94$; Table $11=(0.94+0.99+0.94) / 3=0.96$ Source: Data base of the Far East Forestry Research Institute, 1995.

Table 12 Changes in the proportion of forest land which is mature coniferous stands, 1966-1993.

\begin{tabular}{|l|r|r|r|r|r|r|}
\hline \multirow{2}{*}{$\begin{array}{c}\text { Territorial } \\
\text { units }\end{array}$} & \multicolumn{6}{|c|}{ years } \\
\cline { 2 - 7 } & 1966 & 1973 & 1978 & 1983 & 1988 & 1993 \\
\hline Primorski krai & 45 & 42 & 40 & 31 & 31 & 24 \\
Khabarovski krai & 37 & 36 & 34 & 33 & 33 & 31 \\
Amurskaya oblast & 40 & 31 & 29 & 28 & 27 & 26 \\
Kamchatskaya oblast & 5 & 5 & 6 & 4 & 4 & 4 \\
Magadanskaya oblast & 18 & 16 & 10 & 11 & 12 & 12 \\
Sakhalinskaya oblast & 33 & 33 & 32 & 30 & 29 & 26 \\
SAKhA Republic & 45 & 44 & 41 & 39 & 33 & 33 \\
(Yakutia) & \multicolumn{7}{|c|}{} \\
Source: Data base of the Far East Forestry Research \\
Institute, 1995.
\end{tabular}




\section{CONCLUSION}

This article described the condition of the Far East Forest Service land base as at 1 January 1993. This summary of the forests will remain current until the next inventory on 1 January 1998. Forests dynamics will be included in the inventory only after 1998.

A monitoring service is not yet organized in the Far East which can effectively follow annual changes of forests condition simultaneously over the whole territory of the region. The analysis of forests dynamics in this article used discrete features of the original data substantiate trends and the scope of forestry activities.

Our evaluation of the condition and dynamics of the Far Eastern forests was a general one, oriented toward the key needs of our society. The Far East forests were differentiated into categories which described the quantity of forest and its quality for particular functional values. Forests condition and dynamics categorized by protective function was not consideration this analysis. This type of analysis is important for a better understanding of forest use issues and will be undertaken separately. Such an analysis also be useful for developing methods, view because ways of differentiating between forest functions are insufficiently studied not only in the Russian Far East but also in other regions of the world.

\section{LITERATURE CITED}

Federal Forest Service Russian, (1993): Timber harvesting rules for the Far East forests. Moscow,24pp

Goskomles USSR, (1991): Instructions for the USST Forest Service land base management. Part II.Laboratory activities. Moscow,328 $\mathrm{pp}$

Krechetov, N.I. and Sheingauz, A.S., (1969): The Forest Service land base, The Far East forest. Moscow,13-33

Krechetov, N.I., Chelyshev, V.A. and Sheingauz, A.S, (1975): Main trends of forestry development in heavily forested regions. Moscow, $112 \mathrm{pp}$

Sheingauz, A.S. (1978): Knowledge on forest resources as a bioeconomic approach to nature taiga potential study. Taiga in the global ecosystem the Earth. Irkutsk,42-53

Sheingauz, A.S., (1986): Method recommendations for the Forest Service land base dynamics analysis, Khabazovsk,4lpp

Sheingauz, A.S., (1989): The forest resources of the Far East economics region: State, use, reproduction (normative-reference materials) Khabarovsk,42pp

Sheingauz, A.S. and Chelyshev, V.A., (1984):The forest resources. The issues of the Far East forest complex. Khabarovsk.20-44

Suknomirov, G.I., (1984): Use of nontimber forest resources. The issues of the Far East foenko V.P. rest complex. Khabarovsk,72-89

TARAs, (1976): A forest in economy of a country, Moscow.,143 pp

Tzeplyaev, V.P., (1965): The USSR forestry. Moscow,408pp

Zhiltzov, A.S., (1989) : Evaluation of water-protective role of Primorski krai forests (methodical recommendations). Vladivostok,32 pp

(Received 15 November 1996)

(Accpeted 22 January 1997) 